\section{Осина в Карелии}

\author{
А. А. Кузнецова ${ }^{1}$ \\ Петрозаводский государственный университет
}

\begin{abstract}
АННОТАЦИЯ
Статья посвящена формовому разнообразию осины. Рассматриваются вопросы полового диморфизма осины, формы деревьев по прямизне ствола и цвету коры.
\end{abstract}

Ключевые слова: формовое разнообразие, диморфизм осины, прямоствольность, цвет коры.

\section{SUMMARY}

The article is devoted to the shape variety of aspen. Questions of sex dimorphism of aspen, trees shapes according to the straight of the trunk and the colour of the bark are considered.

Keywords: phenoforms, dimorphism of aspen, straight of trunk, colour of bark.

Осина - дерево высотой до 35 метров и диаметром до 1-1,5 метра. Это одна из самых распространенных пород России. Относится к семейству Ивовые (Salicaceae), к роду Тополь (Populus L.).

Формовое разнообразие осины - проблема не новая. Формы ее могут различаться по строению и цвету коры, срокам распускания и опадения листьев, их размеру. Осина отличается быстротой роста, формой ствола, типом ветвления, способностью очищаться от сучьев, устойчивостью против сердцевинной гнили.

В литературе имеются сведения о наличии разных форм осины. По срокам распускания листьев выделяются две формы: рано распускающиеся и поздно распускающиеся [1 - 5 и др.]. Разница во времени распускания листьев, которая может составлять 6 15 дней, наблюдается между отдельными насаждениями и между отдельными годами [6]. Встречается много промежуточных форм, стоящих ближе то к ранней, то к поздней форме.

На основании наблюдений полевого сезона 2002 года мною были выделены три формы: зеленокорая, серокорая, светлокорая. В 2002 году распускание листьев ранней формы началось на $8-10$ дней раньше, чем поздней. И мужские и женские особи зеленокорой осины имеют только поздно распускающиеся формы. Светлокорая форма осины также имеет только поздно распускающиеся формы, и женские и мужские деревья. Серокорая форма отличается большим разнообразием. Ее деревья имеют рано распускающиеся, поздно распускающиеся и промежуточные формы. В

\footnotetext{
${ }^{1}$ Автор - аспирант кафедры лесного хозяйства (C) А. А. Кузнецова, 2003
}

таблице 1 дано соотношение мужских и женских деревьев.

Распространение мужских и женских деревьев не имеет зависимости от цвета коры и равно 1,5 к 1 у зеленокорой и серокорой форм, а у светлокорой -2 к 1. А распределение деревьев с наличием плодовых тел имеет несколько другое соотношение. У зеленокорых форм - 1 к 1,1 ; у серокорой - 1 к 1 ; у светлокорой -2 к 1 .

Прямоствольность пород имеет важное значение. На каждом участке были выделены деревья с прямой формой ствола, искривленной и промежуточной. К первым относили деревья, у которых ствол был прямой до начала кроны и в ее пределах; у искривленной формы ствол изгибался до начала кроны; у промежуточной формы он был прямым до начала кроны, но терялся или искривлялся в ее пределах.

В таблице 2 дано распределение прямоствольной, искривленной и промежуточной форм осины в зависимости от феноформы. По данным таблицы видно, что распространение прямого ствола наблюдается чаще у поздней фенологической формы. При дальнейших исследованиях на эту зависимость надо обратить более пристальное внимание.

В таблице 3 указаны площади сечения деревьев в зависимости от феноформы и цвета коры. Площадь сечения среднего дерева зависит от феноформы и пола дерева. У зеленокорой поздно распускающейся осины площадь сечения среднего дерева больше у женских особей. У серокорой поздно распускающейся и промежуточной феноформы та же зависимость, а у ранней формы осины зависимость противоположная. У светлокорой поздно распускающейся осины площадь сечения среднего дерева больше у мужских особей, чем у женских.

\section{ВЫВОДЫ:}

1. На обследованных участках были выделены три формы осины: зеленокорая, серокорая, светлокорая;

2. Наибольшим разнообразием морфологических форм отличается серокорая осина;

3. Прямой ствол характерен для поздней феноформы;

4. Площадь сечения среднего дерева зависти от феноформы и пола дерева.

\section{СПИСОК ЛИТЕРАТУРЫ}

1. Данилов М. Д. Рано и поздно распускающиеся формы осины: Бюлл. МОИП, отд. биол. М., 1954. C. 23-39.

2. Марьин Е. М. Формы осины в Карелии // Вопросы селекции, семеноводства и физиологии древесных пород Севера. Петрозаводск, 1967. C. $104-118$.

3. Орленко В. Г. Основные формы осины в лесах Белорусской ССР и их использование в лесном 
хозяйстве // Лесное хозяйство. 1957. № 5. C. 7 - 11.

4. Смилга Я. Я. О здоровых и быстрорастущих формах осины в Латвийской ССР // Повышение продуктивности леса. Рига, 1963.

5. Царев А. П. К характеристике рано и поздно распускающихся форм осины в центральной лесостепи // Известия вузов. Лесной журнал. 1968. № 6. C. 33-37.
6. Щербакова М. А., Веселкова Л. Л. Перспективы селекции в Карелии // Селекция и лесное семеноводство в Карелии. Петрозаводск, 1993. C. $34-40$.

Таблица 1

Соотношение мужских и женских деревьев в зависимости от пола дерева и цвета коры

\begin{tabular}{|c|c|c|c|c|c|}
\hline Феноформа & $\begin{array}{c}\text { Пол } \\
\text { дерева }\end{array}$ & $\begin{array}{c}\text { Общее количе- } \\
\text { ство деревьев, } \\
\text { шт. }\end{array}$ & $\begin{array}{l}\text { Соотношение } \\
\text { мужских и жен- } \\
\text { ских особей }\end{array}$ & $\begin{array}{c}\text { Количество деревьев с } \\
\text { наличием плодовых } \\
\text { тел, шт. }\end{array}$ & $\begin{array}{c}\text { Соотношение муж- } \\
\text { ских и женских осо- } \\
\text { бей с наличием пло- } \\
\text { довых тел } \\
\end{array}$ \\
\hline \multirow{2}{*}{ Зеленокорая } & $\mathrm{M}$ & 160 & \multirow[t]{2}{*}{$1,5 / 1$} & 29 & \multirow[t]{2}{*}{$1 / 1,1$} \\
\hline & Ж & 114 & & 32 & \\
\hline \multirow[t]{2}{*}{ Серокорая } & $\mathrm{M}$ & 163 & \multirow[t]{2}{*}{$1,5 / 1$} & 27 & \multirow[t]{2}{*}{$1 / 1$} \\
\hline & Ж & 118 & & 25 & \\
\hline \multirow[t]{2}{*}{ Светлокорая } & $\mathrm{M}$ & 22 & \multirow[t]{2}{*}{$2 / 1$} & 6 & \multirow[t]{2}{*}{$2 / 1$} \\
\hline & Ж & 11 & & 3 & \\
\hline
\end{tabular}

Таблица 2

Распределение форм осины по прямизне ствола

\begin{tabular}{|c|c|c|c|}
\hline \multirow{2}{*}{ Феноформа } & \multicolumn{3}{|c|}{ Количество деревьев, шт. / \% } \\
\cline { 2 - 4 } & Прямая форма ствола & $\begin{array}{c}\text { Промежуточная } \\
\text { форма ствола }\end{array}$ & $\begin{array}{c}\text { Искривленная } \\
\text { форма ствола }\end{array}$ \\
\hline Ранняя & $136 / 59,4$ & $71 / 31,0$ & $22 / 9,6$ \\
\hline Промежуточная & $45 / 66,2$ & $17 / 25,0$ & $6 / 8,8$ \\
\hline Поздняя & $257 / 70,2$ & $69 / 18,9$ & $40 / 10,9$ \\
\hline Итого & $438 / 66,1$ & $157 / 23,7$ & $68 / 10,2$ \\
\hline
\end{tabular}

Таблица 3

Площади сечения деревьев в зависимости от феноформы и цвета коры

\begin{tabular}{|c|c|c|c|c|}
\hline \multirow{2}{*}{ Феноформа } & \multirow{2}{*}{$\begin{array}{c}\text { Пол } \\
\text { дерева }\end{array}$} & \multicolumn{3}{|c|}{ Площадь сечения дерева, м² / га } \\
\hline & & Зеленый цвет коры & Серый цвет коры & Светлый цвет коры \\
\hline \multirow[t]{2}{*}{ Ранняя } & M & --- & 15,5 & --- \\
\hline & Ж & --- & 13,4 & --- \\
\hline \multirow{2}{*}{ Промежуточная } & M & --- & 8,3 & --- \\
\hline & Ж & --- & 14,3 & --- \\
\hline \multirow[t]{2}{*}{ Поздняя } & $M$ & 17,6 & 9,4 & 20,7 \\
\hline & Ж & 19,5 & 10,7 & 11,1 \\
\hline
\end{tabular}

